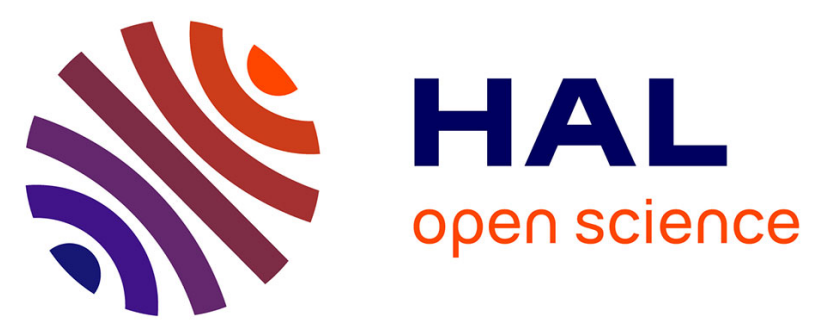

\title{
Electrocatalyzed synthesis of polypeptides on platinum surface in concentrated glycine electrolytes and ab initio calculations coupled to spectroscopic analysis
}

\author{
G. Herlem, S. Monney, V. Blondeau-Patissier, B. Fahys, T. Gharbi
}

\section{- To cite this version:}

G. Herlem, S. Monney, V. Blondeau-Patissier, B. Fahys, T. Gharbi. Electrocatalyzed synthesis of polypeptides on platinum surface in concentrated glycine electrolytes and ab initio calculations coupled to spectroscopic analysis. Electrochimica Acta, 2009, 54 (27), pp.6797-6802. 10.1016/j.electacta.2009.06.051 . hal-00455102

\author{
HAL Id: hal-00455102 \\ https://hal.science/hal-00455102
}

Submitted on 14 Apr 2021

HAL is a multi-disciplinary open access archive for the deposit and dissemination of scientific research documents, whether they are published or not. The documents may come from teaching and research institutions in France or abroad, or from public or private research centers.
L'archive ouverte pluridisciplinaire HAL, est destinée au dépôt et à la diffusion de documents scientifiques de niveau recherche, publiés ou non, émanant des établissements d'enseignement et de recherche français ou étrangers, des laboratoires publics ou privés.

\section{(c)(1)}

Distributed under a Creative Commons Attribution| 4.0 International License 


\title{
Electrocatalyzed synthesis of polypeptides on platinum surface in concentrated glycine electrolytes and $a b$ initio calculations coupled to spectroscopic analysis
}

\author{
Guillaume Herlem $^{\mathrm{a}, *}$, Sandrine Monney ${ }^{\mathrm{a}}$, Virginie Blondeau-Patissier ${ }^{\mathrm{b}}$, Bernard Fahys ${ }^{\mathrm{a}}$, Tijani Gharbi ${ }^{\mathrm{b}}$ \\ a Institut UTINAM UMR CNRS 6213, Bât. N, Université de Franche-Comté, UFR Sciences Ė Techniques, 16 route de Gray, 25030 Besancon Cedex, France \\ b Institut Femto-ST/LPMO CNRS UMR 6174, 25030 Besancon Cedex, France
}

\begin{abstract}
The anodic oxidation of glycine in aqueous electrolyte on smooth platinum electrode was carried out by electrochemical quartz crystal microbalance coupled to cyclic voltammetry technique. Here, we performed electrochemical experiments in concentrated glycine-based electrolyte. Contrary to studies made in diluted medium, the reaction we describe leads to a strongly grafted polymer on the surface at pH values superior to 6 , and up to 13 , in an irreversible way. The electrodeposited mass is even very significant at $\mathrm{pH} 13$. Several methods such as AFM topography and spectroscopic techniques were performed to characterize the resulting coating. The polymer growth in alkaline conditions during the anodic oxidation of glycine in water probably involves an electrocatalytic step. We showed the presence of amide bonds and then polypeptide formation on the smooth platinum surface. Periodic ab initio calculations on polyglycine II were performed and compared to XPS and vibrational spectra.
\end{abstract}

\section{Introduction}

A few years ago, we have shown that the anodic oxidation of pure diamines led to linear polyalkylenimine thin film coatings on surface electrodes [1]. We underlined that these diamines must be primary and that the vicinal carbon need not have to be substituted [2]. Our purpose is to continue our exploration of the anodic oxidation of bifunctional molecules including one primary amine group without substituted $\alpha$ carbon in their structure. In this connection, glycine was used.

Glycine is used in a wide range of applications such as flavor enhancers and maskers, pH buffers and stabilizers, ingredients in pharmaceutical products, and as a chemical intermediate [3]. The first electrochemical studies of amino acids date back to the 60s and focused on their behavior in strong acid solutions where amino acids lead to carboxylic acids, aldehydes, ammonia and carbon dioxide [4].

From the literature, it appears that glycine due to its small size and chemical and biological importance, has attracted extensive attention in recent years with investigations on single crystal electrodes as well as on polycrystalline electrodes [5-10]. They consist in voltammetric studies on single crystal electrode coupled with in situ infrared (FTIRS) or Raman (SERS) spectroscopy and quartz crystal microbalance. On Pt(111) electrode, strongly

\footnotetext{
* Corresponding author. Tel.: +33 03816662 94; fax: +33 0381666294 E-mail address: guillaume.herlem@univ-fcomte.fr (G. Herlem).
}

bonded cyanide is formed above $0.5 \mathrm{~V} / \mathrm{RHE}$ with $\mathrm{CO}_{2}$ generation from the carboxyl group oxidation (Kolbe reaction) [11]. In addition, reversible adsorption of glycinate anions has been detected at potentials higher than $0.3 \mathrm{~V}[4]$.

The anodic oxidation of glycine $10^{-2} \mathrm{M}$ dissolved in phosphate buffered solution of $\mathrm{pH}=7$ on glassy carbon electrodes (GCE) was carried out for elaborating amperometric sensors [12-14]. The authors stated without spectroscopic characterizations, that after their modification procedure (four cyclic scans from -0.5 to $1.8 \mathrm{~V} / \mathrm{SCE}$ ), the GCE was coated by polyglycine.

There are no data concerning highly concentrated glycine-based electrolytes and their electrochemical behavior. Consequently, we used concentrated glycine solutions to enhance any interaction between the electrode surface and their oxidation products. Water was used due to the very weak solubility of glycine in classical organic solvents.

\section{Experimental}

All products were from Sigma-Aldrich (France) and ultra pure water (Milli-Q, Millipore) was used when needed. The electrochemical cell setup, the quartz crystal microbalance (QCM) experiments and attenuated total reflexion infrared spectroscopy (ATR-FTIR) were already described [15]. The three electrodes used are a silver wire reference electrode (SRE), a platinum $\left(10 \mathrm{~cm}^{2}\right)$ counterelectrode and a smooth platinum working electrode.

The cyclic voltammetry measurements were performed either with smooth platinum electrode disk ( $1 \mathrm{~mm}$ diameter) or polished 

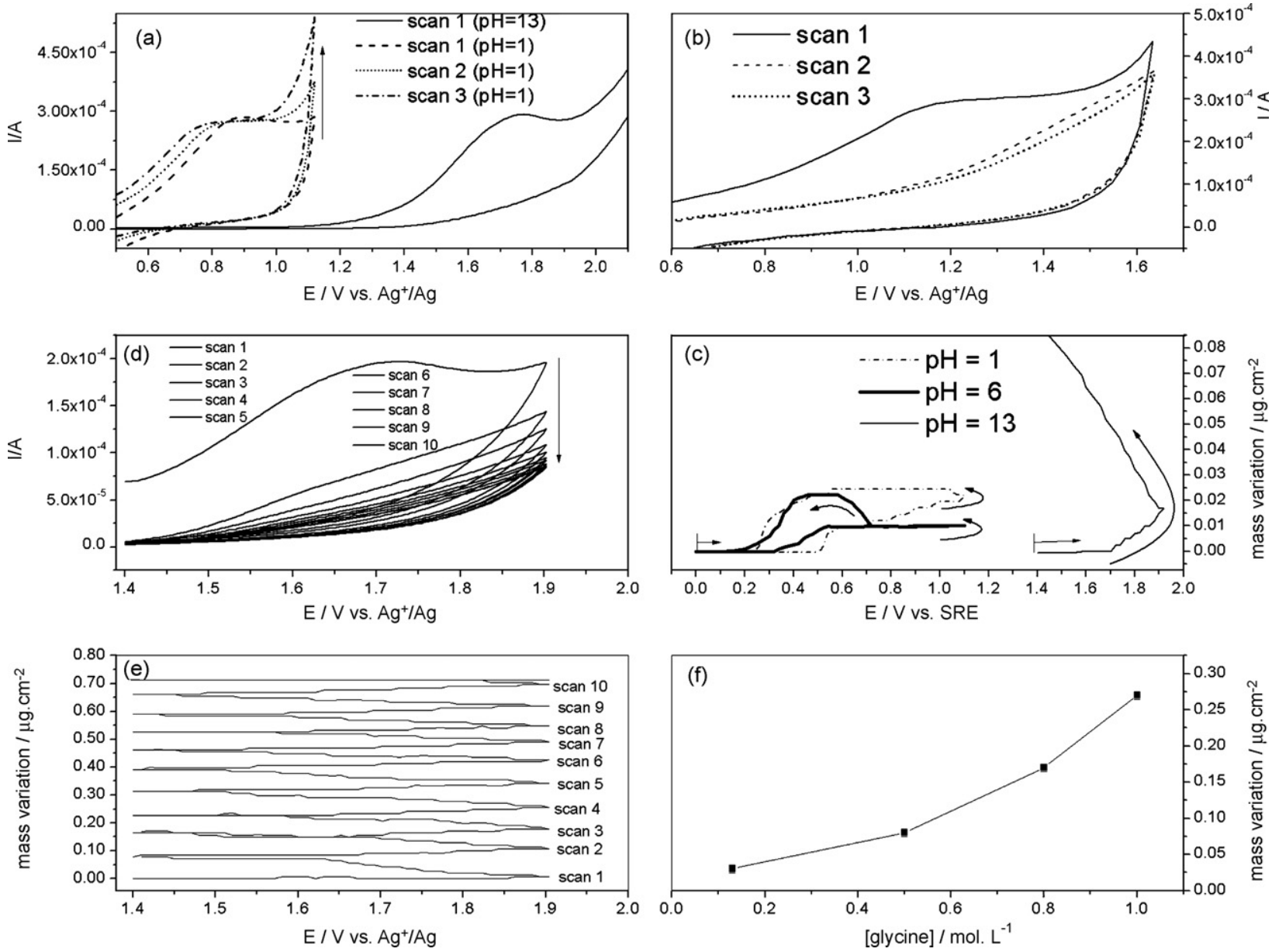

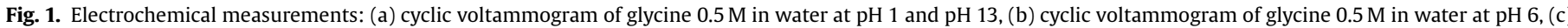

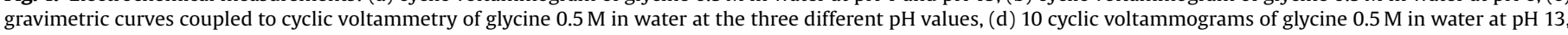

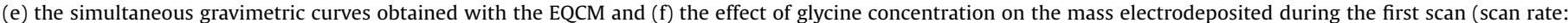
$20 \mathrm{mV} / \mathrm{s}$ ).

platinum-coated quartz crystal ( $5 \mathrm{MHz}$ resonance frequency, area: $1.37 \mathrm{~cm}^{2}$ ) mounted on a PTFE probe and plugged to a PM 710 frequency meter (Maxtek, USA).

Atomic force microscopy (AFM) measurements were performed using a MultiMode AFM microscope controlled by the PicoSPM (Agilent, formerly Molecular Imaging, USA) operating in the contact mode with a gold-coated silicon tip.

X-ray photoelectron spectroscopy (XPS) experiments were carried out using a VG Escalab220i XL spectrometer comprising a rotating anode X-ray source ( $\mathrm{Al} \mathrm{K} \alpha)$, a quartz crystal monochromator, a hemispherical analyser and a multi-channel detector. The vacuum in the analysis chamber was approximately $10^{-10}$ mbar. The slit width was $0.8 \mathrm{~mm}$ and the take off angle was $90^{\circ}$.

\subsection{Computations}

The ab initio periodic approach we used in this work is based on the CRYSTAL06 code, in which crystalline orbitals are obtained from a linear combination of atomic orbitals (LCAO) [16]. All our calculations were carried out at the B3LYP/6-31G(d) level of theory [17].

\section{Results and discussion}

Glycine was dissolved in water and we fixed the glycine concentration to $0.5 \mathrm{M}$. We used $\mathrm{NaBF}_{4} 0.01 \mathrm{M}$ as supporting electrolyte. The different $\mathrm{pH}$ values of the electrolyte were adjusted either with $\mathrm{H}_{2} \mathrm{SO}_{4}$ or $\mathrm{NaOH}$ as needed.

\subsection{Electrochemical measurements}

We carried out cyclic voltammetry experiments between 0 and $2.1 \mathrm{~V}$ vs. SRE as shown in Fig. $1 \mathrm{a}$ and $\mathrm{b}$. There is a Faradaic peak corresponding to the glycine oxidation. Its potential position depends strongly on the $\mathrm{pH}$ value as shown in Fig. 1a, where anodic oxidation experiments were performed at $\mathrm{pH}=1$ and $\mathrm{pH}=13$. Moreover, there is a current drop during cycles at $\mathrm{pH}=6$ (Fig. 1b) and $\mathrm{pH}=13$ (Fig. 1d), which is not present at $\mathrm{pH}=1$. Concerning cyclic voltammetry measurements at $\mathrm{pH}=13$ there is a continuous drop of current during cycles, which is not the case at $\mathrm{pH}=6$ where current drop stabilizes after the second cycle.

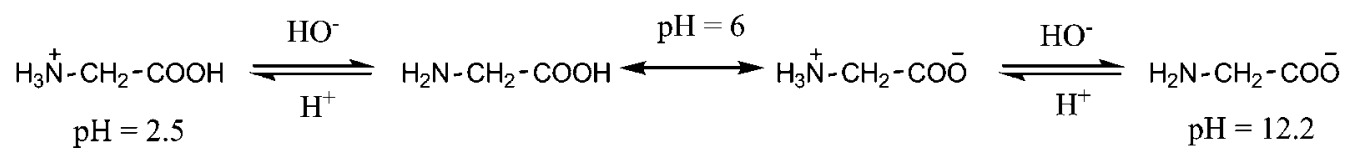

Fig. 2. Glycine forms vs. pH values. 

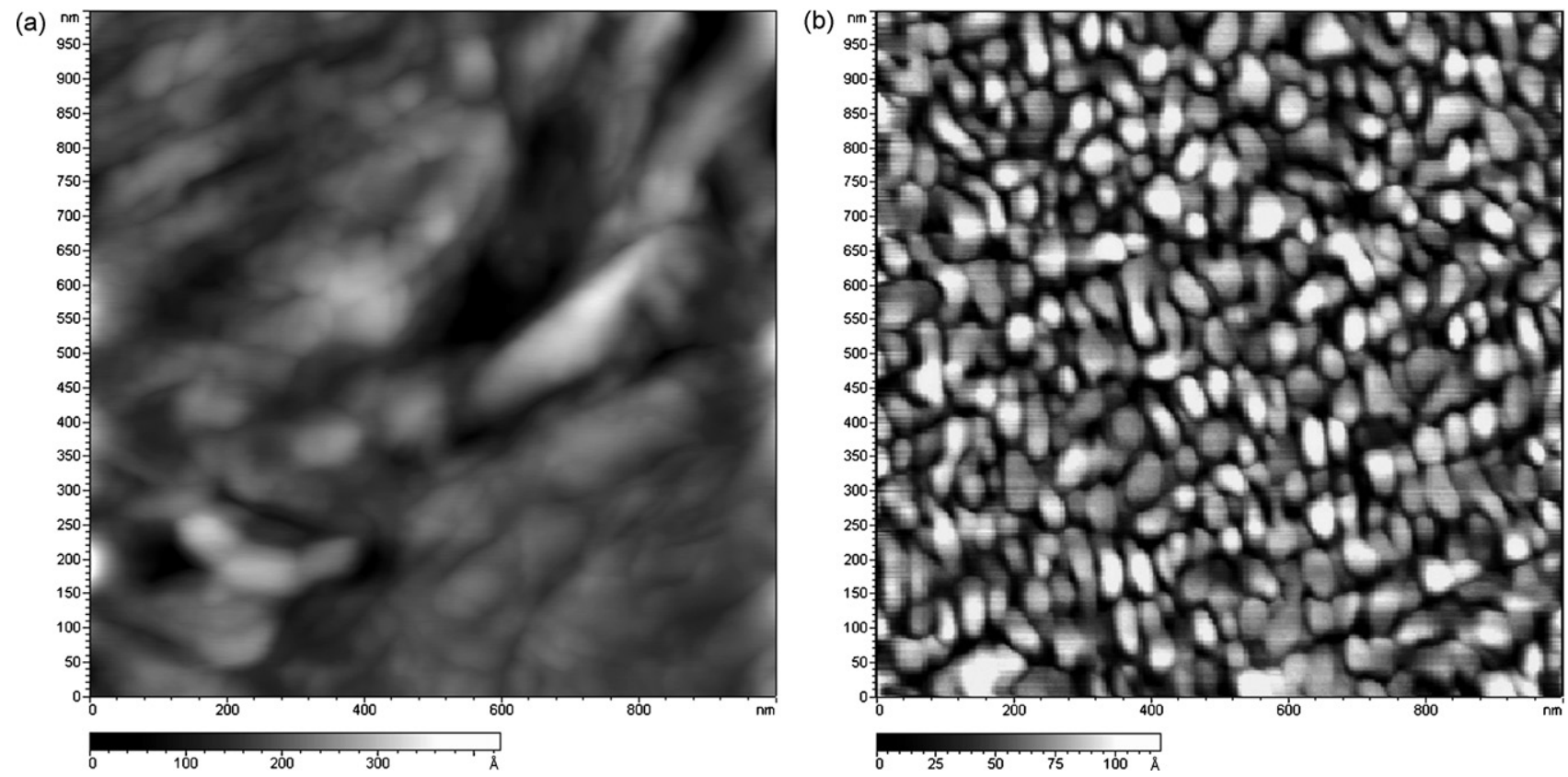

Fig. 3. AFM topography in contact mode of the platinum-coated quartz after 20 voltammetric sweeps (a) compared to (b) the bare platinum surface.

Due to the different forms that glycine can have (acidic, basic or zwitterion) and depicted in Fig. 2, it was necessary to take into account the $\mathrm{pH}$ influence. The higher the $\mathrm{pH}$, the higher the anodic oxidation potential $\mathrm{E}$. The different peak potential values found are $E=0.88 \mathrm{~V}$ at $\mathrm{pH}=1, E=1.15 \mathrm{~V}$ at $\mathrm{pH}=6$ and $E=1.70 \mathrm{~V}$ at $\mathrm{pH}=13$. Furthermore, it is difficult to reach the amine oxidation potential beyond $1.1 \mathrm{~V}(\mathrm{pH}=1)$ and $1.2 \mathrm{~V}(\mathrm{pH}=6)$ vs. SRE (Fig. 1a). In these cases there is a drastic gas bubbling at the working electrode contrary to the electrolyte at $\mathrm{pH}=13$ limiting the anodic voltage to $1.2 \mathrm{~V}$ at $\mathrm{pH}<6$.

The gravimetric curves (Fig. 1c) obtained simultaneously to cyclic voltammetry measurements (Fig. 1a) allow correlating the mass variation at the electrode surface to the $\mathrm{pH}$ and the oxidation potential values. We can see clearly that only at $\mathrm{pH}$ above 13 there is a drastic mass increase beyond the anodic peak potential at $1.7 \mathrm{~V}$ vs. SRE during the forward scan and the mass deposition goes on during the reverse scan. On the contrary at $\mathrm{pH}=1$, the slight mass increase occurred beyond $0.55 \mathrm{~V}$ vs. SRE during the forward scan is completely cancelled during the reverse scan.

Consequently, we focused the electrochemical measurements on the concentrated glycine electrolyte at $\mathrm{pH}=13$ (above $\mathrm{pK}_{\mathrm{a}}=12.2$ ) because the observed electrodeposition is unexpected. We performed 10 scans between 1.4 and $1.9 \mathrm{~V}$ vs. SRE (Fig. 1d). There was a current drop with decreasing peak intensity as the scans proceed. No reverse peak was observed suggesting an irreversible reaction at the platinum surface that yields an insulating coating. Simultaneous EQCM measurements (Fig. 1e) show the constant mass increase at the platinum surface.

Since large electrodeposition occurs at $\mathrm{pH}=13$, we examined the influence of glycine concentration on the mass electrodeposited at the electrode surface in four different glycine concentration electrolytes: $0.13,0.5,0.8$ and $1.0 \mathrm{M}$. We can see from Fig. $1 \mathrm{f}$ that the higher the concentration, the higher the electrodeposited mass quantity. On the other hand, the mass increase is kept constant during the next scan for $0.13 \mathrm{M}$ as for $1.0 \mathrm{M}$ solution. The glycine electrochemical behavior that is quite dependent upon $\mathrm{pH}$ seems similar to that described elsewhere [18]. In the light of spectroelectrochemistry experiments in alkaline solution, the strong chemisorption was reported to take place via the carboxylate group rather than the amino group $[8,19]$.

\subsection{AFM characterization}

Topographic image in Fig. 3a shows a drastic change compared to Fig. 3b depicting the bare platinum surface. The typical platinum nodules (about $50 \mathrm{~nm}$ diameter) have completely disappeared under the electrodeposited coating. Moreover, the scare lines observed are characteristic of stick-slipping interactions between the tip and the coating. This is in favour of the tip sinking into a soft polymeric film electrodeposited on the electrode surface.

\subsection{Spectroscopic measurements}

\subsubsection{ATR-FTIR spectroscopy}

The spectrum of the coating performed at $\mathrm{pH}=13$ is shown Fig. 4 and is different from the glycine one: amide bands are present [20]. These peptide bond formations are electrocatalyzed

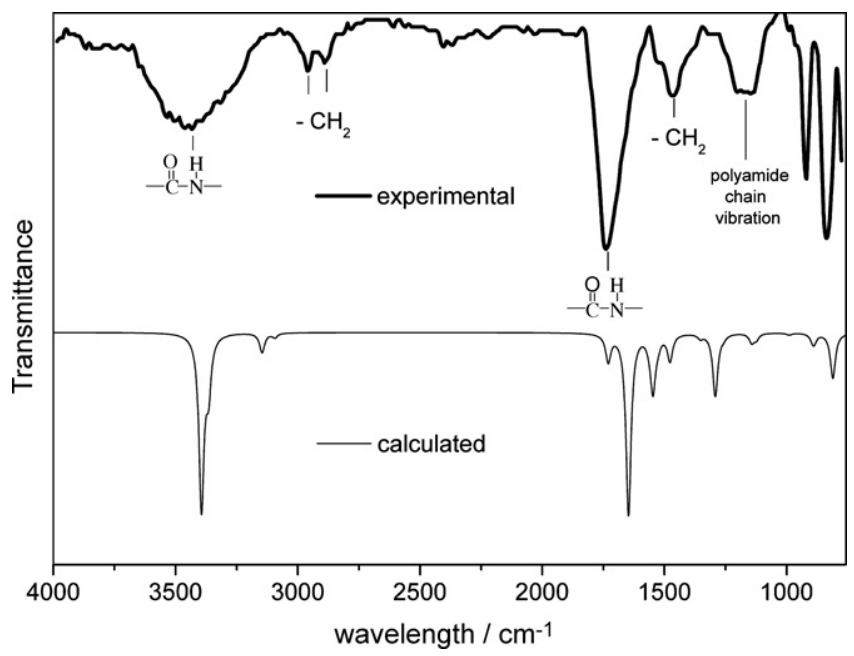

Fig. 4. Spectroscopic characterizations: (a) ATR-FTIR spectrum of the modified smooth platinum quartz after 20 voltammetric sweeps at $\mathrm{pH}=13$ and (b) the calculated spectrum of bulk PG II at the B3LYP/6-31G(d) level of theory. 
Table 1

Atomic fractional coordinates of PG II after structure optimization.

\begin{tabular}{llll}
\hline & $x / a$ & $y / b$ & $z / c$ \\
\hline $\mathrm{O}$ & $4.039940470617 \mathrm{E}-01$ & $1.246858249823 \mathrm{E}-01$ & $-3.003945624409 \mathrm{E}-02$ \\
$\mathrm{C}$ & $1.883527027192 \mathrm{E}-01$ & $2.723424819980 \mathrm{E}-02$ & $6.297502108968 \mathrm{E}-02$ \\
$\mathrm{~N}$ & $2.669024917231 \mathrm{E}-01$ & $5.305403761447 \mathrm{E}-02$ & $2.037625291854 \mathrm{E}-01$ \\
$\mathrm{C}$ & $9.019047792152 \mathrm{E}-02$ & $-5.810782085112 \mathrm{E}-02$ & $3.395824097405 \mathrm{E}-01$ \\
$\mathrm{H}$ & $-4.888312837668 \mathrm{E}-01$ & $1.539254981451 \mathrm{E}-01$ & $2.189255756980 \mathrm{E}-01$ \\
$\mathrm{H}$ & $2.486254521428 \mathrm{E}-01$ & $-8.868006385275 \mathrm{E}-02$ & $4.153444244101 \mathrm{E}-01$ \\
$\mathrm{H}$ & $-1.228711209908 \mathrm{E}-01$ & $-2.972763669120 \mathrm{E}-01$ & $3.272494961210 \mathrm{E}-01$ \\
\hline
\end{tabular}

during the anodic oxidation of the glycine amino group in water. Effectively, pioneer works have shown that the anodic oxidation of primary amine in the presence of water yielded aldehyde via imine bond formation [21]. With no reaction intermediate evidence we can only observe that further oxidation of the glycinate primary amine leads to polyamide formation in alkaline conditions.

The spectral features of our coating are almost identical to those of polyglycine II (noted PG II) oligomers rather than PG I [22]. The presence of $-\mathrm{CH}_{2}$ bending vibrations at $1450-1400 \mathrm{~cm}^{-1}$ is in favour of oligomers too. Due to the tight binding of our coating with the platinum surface and surface dipole selection rule, only vibrational modes which give rise to an oscillating dipole perpendicular to the surface are IR active and give rise to an observable absorption band. In these conditions, some vibration modes can disappear and some others can be enhanced, e.g. the amide III mode in the region $1290-1240 \mathrm{~cm}^{-1}$.

Although PG II was studied theoretically, no complete crystalline structure can be found easily in the literature since models were used [23-28]. In our case, we prefer to perform a vibrational spectrum of PG II from an experimental structure. The best candidate is the only known crystal lattice where atoms crystallize in the $P 3_{1}$ lattice (space group 144). Effectively, bulk calculations with periodic conditions avoid carrying out molecular calculations on long polymer chain. But one of the atoms of the experimental structure was redundant and the given oxygen position was exchanged with one of the two carbons [29]. The rectified structure we obtained was optimized at the B3LYP/6-31G(d) level of theory and the resulting coordinates are shown in Table $1(a=b=4.8 \AA, c=9.3 \AA)$. The structure presents the triple helix along the $c$-axis in agreement with the description made from the X-ray powder diffraction of PG II [30].

The frequency calculation of the vibrational modes at the $\Gamma$ point was performed from the optimized bulk crystal. The results shown in Table 2 present only three imaginary frequencies between 0 and $20 \mathrm{~cm}^{-1}$ corresponding to the translation modes indicating that the global minimum on the potential energy surface is reached. The calculated IR spectrum (plotted with full width at half maximum $20 \mathrm{~cm}^{-1}$ ) with normalized intensities was gathered to the experimental one (no scaling factor used) [31]. Except the $v_{\mathrm{s}}(\mathrm{C}-\mathrm{H})$ of the theoretical spectrum around $3000 \mathrm{~cm}^{-1}$, the frequencies $v$

Table 2

Phonon frequencies computed at the $\Gamma$ center of the Brillouin zone ( $\mathrm{S}=$ symmetry of the irreducible representation).

\begin{tabular}{|c|c|c|c|c|}
\hline Modes & Frequencies $\left(\mathrm{cm}^{-1}\right)$ & $\mathrm{S}$ & Intensities $(\mathrm{km} / \mathrm{mol})$ & Description \\
\hline 1 & -19.9313 & A & 1.54 & $T_{z}$ \\
\hline 2 and 3 & -4.4287 & $\mathrm{E}$ & 0.01 & $T_{x}, T_{y}$ \\
\hline 4 & 63.1867 & A & 10.92 & $v_{\mathrm{t}}(\mathrm{N}-\mathrm{C}-\mathrm{C}) \oplus v_{\mathrm{b}}(\mathrm{N}-\mathrm{H})$ \\
\hline 5 and 6 & 105.3034 & $\mathrm{E}$ & 5.49 & $\nu_{\mathrm{t}}(\mathrm{C}-\mathrm{C}) \oplus \nu_{\mathrm{b}}(\mathrm{N}-\mathrm{C}) \oplus \nu_{\mathrm{b}}(\mathrm{C}-\mathrm{N}-\mathrm{C})$ \\
\hline 7 & 128.161 & A & 1.78 & $v_{\mathrm{t}}(\mathrm{C}-\mathrm{C}) \oplus v_{\mathrm{b}}(\mathrm{C}-\mathrm{N}-\mathrm{C})$ \\
\hline 8 & 168.0291 & A & 0.02 & $v_{t}(C-C)$ \\
\hline 9 and 10 & 192.1621 & $\mathrm{E}$ & 27.77 & $v_{\mathrm{s}}(\mathrm{O} \cdots \mathrm{H}) \oplus v_{\mathrm{t}}(\mathrm{C}-\mathrm{C})$ \\
\hline 11 and 12 & 272.4239 & $\mathrm{E}$ & 14.95 & $v_{\mathrm{t}}(\mathrm{C}-\mathrm{N}) \oplus v_{\mathrm{s}}(\mathrm{O} \cdots \mathrm{H}) \oplus v_{\mathrm{b}}(\mathrm{C}-\mathrm{N}-\mathrm{C}) \oplus v_{\mathrm{b}}(\mathrm{C}-\mathrm{C}-\mathrm{N})$ \\
\hline 13 and 14 & 334.3901 & $\mathrm{E}$ & 45.75 & $v_{\mathrm{s}}(\mathrm{O} \cdots \mathrm{H}) \oplus v_{\mathrm{b}}(\mathrm{C}-\mathrm{C}-\mathrm{N})$ \\
\hline 15 & 340.8932 & A & 0.01 & $v_{\mathrm{t}}(\mathrm{C}-\mathrm{C}) \oplus v_{\mathrm{s}}(\mathrm{O} \cdots \mathrm{H}) \oplus v_{\mathrm{b}}(\mathrm{C}-\mathrm{N}-\mathrm{C})$ \\
\hline 16 and 17 & 497.5683 & $\mathrm{E}$ & 104.33 & $v_{\mathrm{s}}(\mathrm{O} \cdots \mathrm{H}) \oplus v_{\mathrm{b}}(\mathrm{O}-\mathrm{C}-\mathrm{N}) \oplus v_{\mathrm{b}}(\mathrm{C}-\mathrm{N}-\mathrm{C})$ \\
\hline 18 & 523.9135 & A & 113.66 & $v_{\mathrm{t}}(\mathrm{C}-\mathrm{C}) \oplus v_{\mathrm{s}}(\mathrm{O} \cdots \mathrm{H}) \oplus v_{\mathrm{b}}(\mathrm{C}-\mathrm{N}-\mathrm{C})$ \\
\hline 19 and 20 & 565.8745 & $\mathrm{E}$ & 86.65 & $v_{\mathrm{t}}(\mathrm{C}-\mathrm{C}) \oplus v_{\mathrm{s}}(\mathrm{O} \cdots \mathrm{H}) \oplus v_{\mathrm{b}}(\mathrm{O}-\mathrm{C}-\mathrm{N})$ \\
\hline 21 & 574.4654 & A & 126.76 & $v_{\mathrm{t}}(\mathrm{C}-\mathrm{C}) \oplus v_{\mathrm{b}}(\mathrm{C}=\mathrm{O}) \oplus v_{\mathrm{t}}(\mathrm{C}-\mathrm{N})$ \\
\hline 22 & 644.8448 & A & 45.47 & $\nu_{\mathrm{s}}(\mathrm{C}-\mathrm{C}) \oplus \nu_{\mathrm{b}}(\mathrm{C}=\mathrm{O}) \oplus \nu_{\mathrm{b}}(\mathrm{C}-\mathrm{C}-\mathrm{N})$ \\
\hline 23 and 24 & 713.0935 & $\mathrm{E}$ & 44.75 & $\nu_{\mathrm{b}}(\mathrm{C}-\mathrm{N}-\mathrm{C}) \oplus v_{\mathrm{b}}(\mathrm{C}=\mathrm{O}) \oplus \nu_{\mathrm{b}}(\mathrm{O}-\mathrm{C}-\mathrm{N})$ \\
\hline 25 & 808.7982 & A & 12.07 & $\nu_{\mathrm{b}}(\mathrm{C}=\mathrm{O}) \oplus v_{\mathrm{b}}(\mathrm{N}-\mathrm{H})$ \\
\hline 26 and 27 & 810.607 & $\mathrm{E}$ & 602.13 & $\nu_{\mathrm{b}}(\mathrm{C}=\mathrm{O}) \oplus \nu_{\mathrm{b}}(\mathrm{N}-\mathrm{H})$ \\
\hline 28 and 29 & 888.2009 & $\mathrm{E}$ & 123.89 & $v_{\mathrm{b}}(\mathrm{C}-\mathrm{N}-\mathrm{C}) \oplus v_{\mathrm{s}}(\mathrm{C}-\mathrm{N}) \oplus v_{\mathrm{s}}(\mathrm{C}-\mathrm{C}) \oplus v_{\mathrm{r}}\left(\mathrm{CH}_{2}\right)$ \\
\hline 30 & 894.929 & A & 52.26 & $v_{\mathrm{b}}(\mathrm{C}-\mathrm{N}-\mathrm{C}) \oplus v_{\mathrm{s}}(\mathrm{C}-\mathrm{N}) \oplus v_{\mathrm{s}}(\mathrm{C}-\mathrm{C})$ \\
\hline 31 and 32 & 989.5726 & $\mathrm{E}$ & 26.85 & $v_{\mathrm{s}}(\mathrm{C}-\mathrm{C}) \oplus v_{\mathrm{r}}\left(\mathrm{CH}_{2}\right) \oplus v_{\mathrm{b}}(\mathrm{N}-\mathrm{H})$ \\
\hline 33 & 1036.3215 & A & 0.76 & $\nu_{\mathrm{b}}(\mathrm{C}-\mathrm{N}-\mathrm{C}) \oplus v_{\mathrm{b}}(\mathrm{N}-\mathrm{H}) \oplus \nu_{\mathrm{r}}\left(\mathrm{CH}_{2}\right) \oplus v_{\mathrm{s}}(\mathrm{C}-\mathrm{C})$ \\
\hline 34 and 35 & 1124.4795 & $\mathrm{E}$ & 80.44 & $v_{\mathrm{s}}(\mathrm{C}-\mathrm{N}) \oplus v_{\mathrm{s}}(\mathrm{C}-\mathrm{C}) \oplus v_{\mathrm{b}}(\mathrm{N}-\mathrm{H}) \oplus v_{\mathrm{tw}}\left(\mathrm{CH}_{2}\right)$ \\
\hline 36 & 1143.2258 & A & 124.74 & $v_{\mathrm{s}}(\mathrm{C}-\mathrm{N}) \oplus v_{\mathrm{s}}(\mathrm{C}-\mathrm{C}) \oplus v_{\mathrm{b}}(\mathrm{N}-\mathrm{H}) \oplus v_{\mathrm{tw}}\left(\mathrm{CH}_{2}\right)$ \\
\hline 37 & 1250.7152 & A & 1.35 & $v_{\mathrm{tw}}\left(\mathrm{CH}_{2}\right)$ \\
\hline 38 and 39 & 1257.8467 & $\mathrm{E}$ & 39.54 & $v_{\mathrm{tw}}\left(\mathrm{CH}_{2}\right)$ \\
\hline 40 & 1292.3091 & A & 851.36 & $v_{\mathrm{s}}(\mathrm{C}-\mathrm{N}) \oplus v_{\mathrm{w}}(\mathrm{H}-\mathrm{C}-\mathrm{H})$ \\
\hline 41 and 42 & 1353.2516 & $\mathrm{E}$ & 57.64 & $v_{\mathrm{s}}(\mathrm{C}-\mathrm{N}) \oplus v_{\mathrm{s}}(\mathrm{C}-\mathrm{C}) \oplus v_{\mathrm{w}}(\mathrm{H}-\mathrm{C}-\mathrm{H})$ \\
\hline 43 and 44 & 1476.3936 & $\mathrm{E}$ & 209.65 & $\nu_{\mathrm{s}}(\mathrm{C}-\mathrm{N}) \oplus v_{\mathrm{s}}(\mathrm{C}-\mathrm{C}) \oplus \nu_{\mathrm{w}}(\mathrm{H}-\mathrm{C}-\mathrm{H})$ \\
\hline 45 & 1479.0858 & A & 152.40 & $v_{\mathrm{s}}(\mathrm{C}-\mathrm{N}) \oplus v_{\mathrm{b}}(\mathrm{N}-\mathrm{H}) \oplus v_{\mathrm{w}}(\mathrm{H}-\mathrm{C}-\mathrm{H})$ \\
\hline 46 and 47 & 1527.2613 & $\mathrm{E}$ & 97.84 & $v_{\mathrm{s}}(\mathrm{C}-\mathrm{N}) \oplus v_{\mathrm{b}}(\mathrm{N}-\mathrm{H}) \oplus v_{\mathrm{w}}(\mathrm{H}-\mathrm{C}-\mathrm{H})$ \\
\hline 48 & 1545.7056 & A & 332.47 & $v_{\mathrm{s}}(\mathrm{C}-\mathrm{N}) \oplus v_{\mathrm{s}}(\mathrm{C}-\mathrm{C}) \oplus v_{\mathrm{b}}(\mathrm{N}-\mathrm{H}) \oplus v_{\mathrm{w}}(\mathrm{H}-\mathrm{C}-\mathrm{H})$ \\
\hline 49 and 50 & 1548.3278 & $\mathrm{E}$ & 431.88 & $v_{\mathrm{s}}(\mathrm{C}=\mathrm{O}) \oplus v_{\mathrm{s}}(\mathrm{C}-\mathrm{C}) \oplus v_{\mathrm{s}}(\mathrm{C}-\mathrm{N}) \oplus v_{\mathrm{b}}(\mathrm{C}-\mathrm{H}) \oplus v_{\mathrm{b}}(\mathrm{N}-\mathrm{H})$ \\
\hline 51 & 1562.8006 & A & 68.83 & $v_{\mathrm{s}}(\mathrm{C}=\mathrm{O}) \oplus v_{\mathrm{s}}(\mathrm{C}-\mathrm{C}) \oplus v_{\mathrm{s}}(\mathrm{C}-\mathrm{N}) \oplus v_{\mathrm{b}}(\mathrm{C}-\mathrm{H})$ \\
\hline 52 & 1647.1651 & A & 2455.55 & $v_{\mathrm{s}}(\mathrm{C}=\mathrm{O}) \oplus v_{\mathrm{w}}(\mathrm{H}-\mathrm{C}-\mathrm{H})$ \\
\hline 53 and 54 & 1730.4733 & $\mathrm{E}$ & 363.62 & $v_{\mathrm{s}}(\mathrm{C}=\mathrm{O}) \oplus v_{\mathrm{s}}(\mathrm{C}-\mathrm{N}) \oplus v_{\mathrm{w}}(\mathrm{H}-\mathrm{C}-\mathrm{H}) \oplus v_{\mathrm{b}}(\mathrm{C}-\mathrm{H})$ \\
\hline 55 & 3092.9124 & A & 36.91 & $v_{\mathrm{as}}(\mathrm{C}-\mathrm{H})$ \\
\hline 56 and 57 & 3093.7382 & $\mathrm{E}$ & 22.91 & $v_{\mathrm{ss}}(\mathrm{C}-\mathrm{H})$ \\
\hline 58 & 3144.3359 & A & 8.14 & $v_{s s}(\mathrm{C}-\mathrm{H})$ \\
\hline 59 and 60 & 3145.6485 & $\mathrm{E}$ & 256.93 & $v_{\mathrm{as}}(\mathrm{N}-\mathrm{H})$ \\
\hline 61 & 3365.1201 & A & 697.08 & $v_{\mathrm{as}}(\mathrm{N}-\mathrm{H})$ \\
\hline 62 and 63 & 3393.921 & $\mathrm{E}$ & 2353.57 & $v_{\mathrm{ss}}(\mathrm{N}-\mathrm{H})$ \\
\hline
\end{tabular}

$\mathrm{s}=$ stretching, $\mathrm{ss}=$ symmetric stretching, as = asymmetric stretching, $\mathrm{w}=$ wagging, $\mathrm{b}=$ bending, $\mathrm{r}=$ rocking, tw $=\mathrm{twist}, \mathrm{T}=$ translation, $\mathrm{t}=$ torsion . 

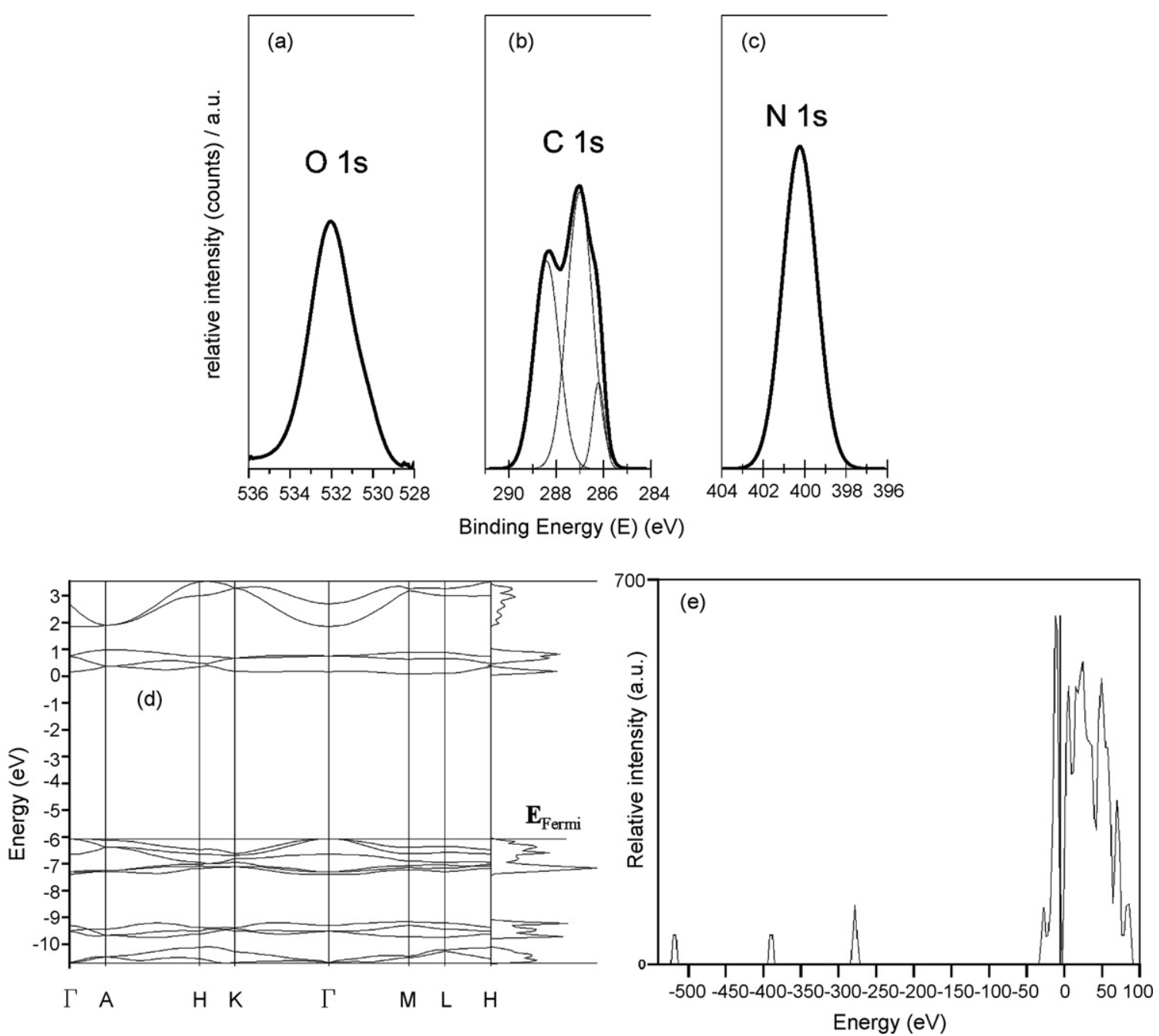

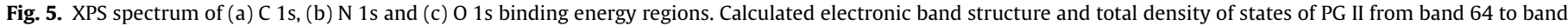
82 (total of 186 bands) at the B3LYP/6-31G(d) level of theory.

of the two spectra match very well. On the other hand it is difficult to compare the intensities because in one case we investigate the bulk crystal and in another case we study the thin film polymer chemisorbed on a platinum surface. From our calculations, the characteristic polyamide skeletal stretching bands for PG II (bulk) are spread over bands between 900 and $1150 \mathrm{~cm}^{-1}$. The experimental spectrum shows this visible broad band at $1100 \mathrm{~cm}^{-1}$. Moreover, glycinate strongly adsorbs and despite rinsing several times the surface, this ion can give rise to the vibration band around $1400 \mathrm{~cm}^{-1}$ [9]. In this context, FTIR spectra obtained after anodic oxidation of glycine clearly bring out a strong band at $1460 \mathrm{~cm}^{-1}$, which corresponds to $v(\mathrm{O}-\mathrm{C}-\mathrm{O})$ of the glycinate ion adsorbed on platinum. This strong mode is not important in our theoretical vibrational spectrum since bulk polyglycine II was modelized.

\subsubsection{XPS analysis}

The XPS spectra are displayed in Fig. 5. We obtained at $5 \mathrm{eV}$ a pre-peak which is characteristic of a polymeric structure. Fig. 5a in the $O 1 \mathrm{~s}$ region reveals an asymmetric peak at $531.8 \mathrm{eV}$ attributed to $-\mathrm{C}=\mathrm{O}$ in polyamide bond and agrees well carboxylate energy binding. Two $\mathrm{C} 1 \mathrm{~s}$ peaks are clearly resolved in Fig. $5 \mathrm{~b}$. The peak at $287 \mathrm{eV}$ can be attributed to $-\mathrm{CH}_{2}$, while the other at 288.8 can be assigned to $-\mathrm{C}=\mathrm{O}$. The peak areas give a ratio of $1-\mathrm{C}=\mathrm{O}$ for $1-\mathrm{CH}_{2}$. The peak at $286 \mathrm{eV}$ seems to be intrinsic to glycine system [32]. As shown in Fig. $5 \mathrm{c}$ there is one peak in the $\mathrm{N} 1 \mathrm{~s}$ region at $401 \mathrm{eV}$. Depending on the pH during the electrosynthesis and the rinsing conditions an additional peak can appear at $402 \mathrm{eV}$, which corresponds to the protonated amino group. The energy binding corresponds to amide bond at $401 \mathrm{eV}$. The XPS data are in good agreement with results concerning bulk PG and radically different from glycine adsorbed on Pt(111) [19,33], where cyanide groups were present. This is not the case on our modified platinum surface underlying the radical change when performing anodic oxidation experiments with concentrated glycine-based electrolyte. Band structure calculations around the Fermi energy level show the insulating state of PG II with a bandgap of $6.1 \mathrm{eV}$ at this level of theory (Fig. 5d). This band gap energy confirms the electrical insulating property of the resulting polyglycine-like film and then the current drop during cyclic voltammetry scans.

The density of states (DOS) displayed in Fig. 5e and performed on the whole band structure exhibit the binding energies of $\mathrm{N} 1 \mathrm{~s}$ and $\mathrm{O} 1 \mathrm{~s}$ at -519 and $-391 \mathrm{eV}$, respectively [34]. These values are quite close to the XPS values in the Koopman's approximation and by taking into account the bandgap energy for solids. From our calculations, we also find two $\mathrm{C} 1$ s peaks at -280 and $-278 \mathrm{eV}$ corresponding to $-\mathrm{C}=\mathrm{O}$ (amide) and $-\mathrm{CH}_{2}$, respectively.

\section{Conclusions}

We have presented an original work on the anodic oxidation of aqueous concentrated glycine-based electrolytes that yields polyglycine-like coating on smooth platinum electrode surface. 
We have underlined this unexpected behavior by coupling EQCM experiments to cyclic voltammetry method. It is another new way amongst all those existing to functionalize surfaces (conducting or semiconducting) with an insulating thin film for further applications such as molecule grafting or sensor/biosensors.

Surface characterization of modified surfaces by AFM technique allows us to verify we were not in presence of a monolayer. Periodic $a b$ initio calculations from an optimized existing structure and coupled to spectroscopic analysis (XPS and IR) were relevant to unequivocally assign bands.

As an attempt to explain the polypeptide growth during the anodic oxidation of concentrated glycine, we plan in a future work to elucidate the intermediate species and to propose a reaction mechanism.

\section{References}

[1] B. Lakard, G. Herlem, M. Herlem, J. Morvan, A. Etcheberry, B. Fahys, Surf. Sci. 502-503 (2002) 296.

[2] G. Herlem, K. Reybier, A. Troukourey, B. Fahys, J. Electrochem. Soc. 147 (2000) 597.

[3] F. Franek, et al., Biotechnol. Prog. 18 (2002) 155.

[4] H. Lund, M. Baizer (Eds.), Organic Electrochemistry, 3rd edition, Marcel Dekker, Inc., 1991, ISBN 0-8247-8154-6, p. 601, and 3 references therein.

[5] F. Huerta, E. Morallón, F. Cases, A. Rodes, J.L. Vásquez, A. Aldaz, J. Electroanal. Chem. 421 (1997) 179.

[6] C.-H. Zhen, S.-G. Sun, C.-J. Fan, S.-P. Chen, B.W. Mao, Y.-P. Chen, Electrochem. Acta 49 (2004) 1249.

[7] S.M. MacDonald, S.G. Roscoe, Electrochem. Acta 42 (1997) 1189.

[8] K. Ogura, M. Kobayashi, M. Nakayama, Y. Miho, J. Electroanal. Chem. 449 (1998) 101.
[9] K. Ogura, M. Nakayama, K. Nakaoka, Y. Nishihata, J. Electroanal. Chem. 482 (2000) 32.

[10] A. Lori, T. Hanawa, Corros. Sci. 43 (2001) 2111

[11] X.-Y. Xiao, S.-G. Sun, J.-L. Yao, Q.-H. Wu, Z.-Q. Tian, Langmuir 18 (2002) 6274

[12] A.-M. Yu, H.-L. Zhang, H.-Y. Chen, Analyst 122 (1997) 839.

[13] H.-Y. Chen, A.-M. Yu, H.-L. Zhang, Fresenius J. Anal. Chem. 358 (1997) 863.

[14] L. Zhang, X. Lin, Fresenius J. Anal. Chem. 370 (2001) 956.

[15] G. Herlem, O. Segut, A. Antoniou, C. Achilleos, D. Dupont, V. Blondeau-Patissier, T. Gharbi, Surf. Coat. Technol. 202 (2008) 1437.

[16] R. Dovesi, V.R. Saunders, C. Roetti, R. Orlando, C.M. Zicovich-Wilson, F. Pascale, B. Civalleri, K. DolL, N.M. Harrison, I. J. Bush, Ph. D'Arco, M. Llunell, CRYSTAL06 (2007) v1.0.2.

[17] R. Improta, V. Barone, K.N. Kudin, G.E. Scuseria, J. Chem. Phys. 114 (2001) 2541.

[18] N.C. Reynolds, B.M. Kissela, L.H. Fleminf, Electroanalysis 7 (1995) 1177.

[19] G. Horányi, E.M. Rizmayer, J. Electroanal. Chem. 198 (1986) 393.

[20] M. Rosado, M.L.T.S. Duarte, R. Fausto, Vibr. Spectrosc. 16 (1998) 35

[21] C.K. Mann, K.A. Barnes, Electrochemical Reactions in Nonaqueous Systems, Dekker, New York, 1970, pp. 259-296 (Chap. 8).

[22] K. Taga, et al., Vibr. Spectrosc. 14 (1997) 143.

[23] V. Sasisekharan, V.N. Balaji, Macromolecules 12 (1979) 28

[24] A.M. Dwivedi, S. Krimm, Biopolymers 21 (1982) 2377.

[25] R.H. Scheicher, D. Cammarere, N. Sahoo, K. Nagamine, T.P. Das, Z. Naturforsch. $57 a(2002) 523$.

[26] W. Yun-Dong, Z. Yi-Lei, J. Am. Chem. Soc. 123 (2001) 5313.

[27] S. SCheiner, C.W. Kern, Proc. Natl. Acad. Sci. U.S.A. 75 (1978) 2071

[28] Y. Abe, S. Krimm, Biopolymers 11 (1972) 1841.

[29] G.N. Ramachandran, V. Sasisekharan, C. Ramakrishnan, Biochim. Biophys. Acta 112 (1966) 168.

[30] F.H.C. Crick, A. Rich, Nature 176 (1955) 780.

[31] P. Ugliengo, D. Viterbo, G. Chiari, Z. Kristallogr. 207 (1993) 9.

[32] P. Löfgren, Surf. Sci. 370 (1997) 277.

[33] C. Avisek, Z. Liyan, Z. Lei, P. Debabrata, Z. Xiaojing, K.T. Leung, J. Chem. Phys. 129 (2008) 105104

[34] B.G. Searle, Comput. Phys. Commun. 137 (2001) 25 